\title{
STRATEGI PEMBANGUNAN BERWAWASAN LINGKUNGAN KAWASAN PERMUKIMAN SEGI EMPAT EMAS TUNJUNGAN SURABAYA
}

\author{
Septi Dwi Cahyani ${ }^{(1)}$, Rendra Suprobo Aji ${ }^{(2)}$ \\ (1)Program Studi Arsitektur Universitas Merdeka Malang, septi.cahyani@unmer.ac.id \\ (2)Program Studi Perencanaan Wilayah Kota, Universitas Jember
}

\begin{abstract}
ABSTRAK
Pembangunan berwawasan lingkungan merupakan suatu upaya memaksimalkan potensi Sumber Daya Alam yang ada secara terencana, bertanggung jawab, dan sesuai dengan daya dukungnya. Kemakmuran rakyat, kelestarian fungsi, dan keseimbangan lingkungan hidup merupakan hal yang utama dalam mendukung pembangunan berwawasan lingkungan sebagai wujud penerapan keberlanjutan. Pembentukan suatu kota sebenarnya diawali oleh keberadaan kampung, tak terkecuali Kota Surabaya. Seiring berjalannya waktu, permukiman penduduk asli yang terbentuk sebagai cikal bakal kampung berkembang dengan kemunculan ragam etnis dari berbagai wilayah. Sekelompok masyarakat dengan latar sosial budaya tertentu membentuk kampung-kampung yang keberadaanya masih dapat dipertahankan dari pihak-pihak yang berkepentingan. Permukiman di Kawasan Segi Empat Emas Tunjungan Surabaya merupakan salah satu kawasan permukiman yang masih mampu bertahan di tengah-tengah area percepatan pertumbuhan bisnis. Permukiman ini dinilai memiliki karakter yang patut dipertahankan karena turut menjadi saksi bersejarah dari identitas kawasannya berada pada cakupan wilayah konservasi. Untuk menjaga eksistensi dari kawasan permukiman tersebut, pentingnya menyusun strategi pembangunan permukiman berwawasan lingkungan melalui temuan masalah yang ditangani berdasarkan konsep lingkungan (permukiman ekologis, arsitektur hijau), ekonomi (pembangunan ekonomi berwawasan lingkungan), dan peran masyarakat setempat sehingga dapat menunjang pembangunan optimal.
\end{abstract}

Kata kunci - Kampung Kota, Pembangunan Berwawasan Lingkungan, Permukiman, Tunjungan.

\section{PENDAHULUAN}

\subsection{Latar Belakang}

Pembentukan suatu kota sebenarnya diawali oleh keberadaan kampung (Djau, 2010). Kampung terbentuk dari cikal bakal penduduk asli dimana perkembangannya menarik pendatang baru dengan beragam latar belakang etnis budaya untuk bermukim. Seiring dengan pesatnya pertambahan penduduk permukiman kampung di wilayah perkotaan, wacana permasalahan slum dan squatter menjadi masalah stereotipe yang penting untuk segera ditindaklanjuti (Nursyahbani \& Pigawati, 2015; Widjaja, 2013). Bagaimanapun, penyelesaian permasalahan teknis yang ada di permukiman kampung kota tidak hanya sekedar pada wacana lingkungan kumuh dan liar, namun lebih menyeluruh pada pembangunan berwawasan lingkungan (Hamidah, Rijanta, Setiawan, \& Marfai, 2016).

Pembangunan berwawasan lingkungan memberi keberimbangan perhatian tidak hanya pada lingkungan fisik, namun juga pada aspek perekonomian dan 
kehidupan masyarakat. Oleh karenanya, kemakmuran rakyat, kelestarian fungsi, dan keseimbangan lingkungan hidup merupakan indikator keberhasilan utama dalam keberlanjutan pembangunan berwawasan lingkungan (Hall \& Pfeiffer, 2013; Jazuli, 2015). Dalam hal ini, pembangunan berwawasan lingkungan mengedepankan pengelolaan potensi Sumber Daya Alam yang ada di suatu kawasan secara terencana, bertanggung jawab, dan sesuai dengan daya dukungnya agar tidak memunculkan problematika degradasi pada kualitas lingkungan hidup dan kehidupan manusianya (Daniels, 2017).

Pengelolaan perekonomian sebagai bagian dari pembangunan berwawasan lingkungan perlu mendapat pemikiran lebih ketika permukiman kampung berada pada lingkungan perekonomian masif, seperti di pusat perkotaan. Percepatan pertumbuhan ekonomi dalam suatu kawasan perkotaan menuntut adanya perubahan atau perkembangan tatanan ruang yang kontinu (Daniels, 2017). Untuk dapat mengimbangi kondisi lingkungan, keberadaan kampung kota harus dapat memberi kontribusi positif terhadap lingkungannya termasuk peningkatan sosio-kultural sejalan dengan pertumbuhan perekonomian di kawasan eksternal (Nazaruddin, 2015) agar tidak tercipta kesenjangan.

Permukiman di Kawasan Segi Empat Emas Tunjungan Surabaya, misalnya, merupakan salah satu permukiman kampung kota yang memerlukan pengelolaan berkelanjutan dalam pembangunan berwawasan lingkungan. Wilayahnya berada di tengah-tengah area percepatan pertumbuhan bisnis. Cukup mendesak ketika kawasan permukiman berada pada "kawasan emas" dengan dominasi pusat kegiatan perekonomian kota sebagai area perdagangan, jasa, dan perkantoran.
Sementara di sisi lainnya, permukiman ini dinilai memiliki karakter yang penting untuk dipertahankan karena turut menjadi saksi sejarah dan identitas kawasan (Damayanti, 2017; Djau, 2010).

Menyusun strategi pembangunan berwawasan lingkungan pada permukiman merupakan hal mendasar sebagai bentuk penjagaan eksistensi kawasan. Berdasarkan hal tersebut, beberapa upaya yang berusaha dilakukan ialah dengan merumuskan konsep ekologis/ berwawasan lingkungan melalui pendekatan lingkungan fisik (arsitektur hijau), ekonomi berwawasan lingkungan, serta sosial masyarakat (peran masyarakat setempat).

\subsection{Wilayah Studi}

Lokasi amatan berada di Unit Pengembangan (UP) Tunjungan yang terletak di Pusat Kota Surabaya (Kecamatan Genteng, Kelurahan Genteng) (Bappeko, 2010). Kawasan ini terdiri dari 4 RW dengan 32 RT dimana secara historis karakteristik permukiman kampungnya terbentuk secara mandiri. Secara umum, kawasan permukiman ini berada pada luasan $\pm 20 \mathrm{Ha}$ dengan batas wilayah fisik yaitu Jalan Praban (batas Utara), Jalan Embong Malang (batas Selatan), Jalan Blauran (batas Barat), dan Jalan Tunjungan (batas Timur). Gambar 1. merupakan peta pemanfaatan lahan kawasan Segi Empat Emas Tunjungan (area permukiman diberi tanda warna kuning).

Kawasan permukiman Segi Empat Emas Tunjungan dikelilingi oleh sektor - sektor komersial dengan skala pelayanan lokal hingga regional. Kegiatan ekonomi skala regional diperlihatkan pada kegiatan perdagangan mall, ruko, perkantoran, dan perbankan. Sementara itu, skala pelayanan lokal ditunjukkan melalui kegiatan 
perdagangan toko kelontong, pasar tradisional, dan lainnya. Oleh karenanya, wiraswasta, pedagang, pelayanan jasa, dan karyawan perusahaan menjadi mata pencaharian mayoritas penduduk kawasan permukiman Tunjungan.

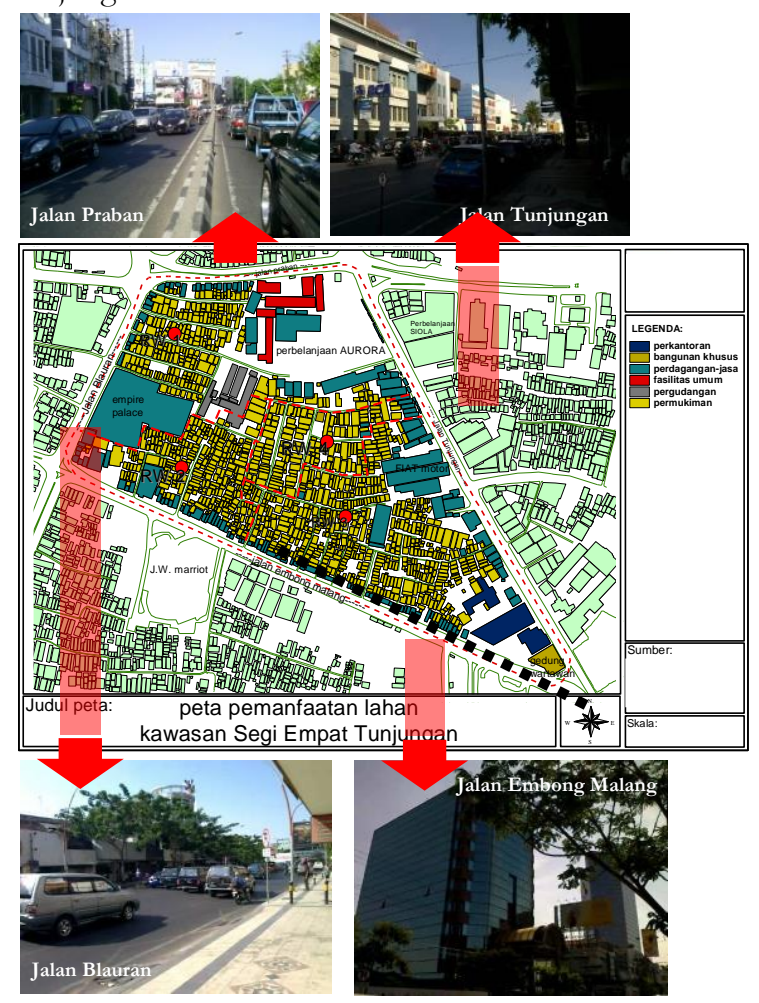

Gambar 1. Peta Pemanfaatan Lahan Kawasan Segi Empat Emas Tunjungan (sumber: hasil survei)

Usia produktif diketahui menduduki sebaran dominan di dalam kawasan, meskipun laju pertumbuhan penduduk memperlihatkan angka penurunan (Bappeko, 2010).
Bagaimanapun, penurunan ini tidak dipandang sebagai suatu permasalahan dalam melihat potensi perekonomian setempat. Sebagian besar pemilik hunian memanfaatkan lahan hunian mereka sebagai lahan usaha (Tabel 1.) sebagai imbas dari nilai komersial lingkungan. Tidak hanya memberi keuntungan pada pemilik hunian, namun juga memberi nilai guna hunian untuk masyarakat sekitar. Sebagai misal, hunian digunakan sebagai area bermukim sementara bagi para pekerja yang bekerja di kawasan komersial Tunjungan. Tanpa disadari, kondisi ini jugalah yang menimbulkan pergerakan heterogen dari etnis kelompok yang secara turun temurun mendiami lokasi permukiman.

Tabel 1. Jenis Kegiatan Perekonomian Masyarakat Permukiman Segi Empat Tunjungan

\begin{tabular}{|c|c|c|}
\hline $\begin{array}{c}\text { JENIS } \\
\text { KEGIATAN }\end{array}$ & $\begin{array}{c}\text { LOKASI } \\
\text { KEGIATAN }\end{array}$ & $\begin{array}{c}\text { SKALA } \\
\text { PELAYANAN }\end{array}$ \\
\hline $\begin{array}{ll}\text { Usaha } & \text { rumah } \\
\text { tangga }\end{array}$ & $\begin{array}{l}\text { Masing-masing } \\
\text { rumah }\end{array}$ & lokal \\
\hline Usaha sewa (kos) & $\begin{array}{l}\text { Masing-masing } \\
\text { rumah }\end{array}$ & lokal \\
\hline $\begin{array}{l}\text { Usaha pedagang } \\
\text { keliling }\end{array}$ & $\begin{array}{l}\text { Lingkungan } \\
\text { permukiman }\end{array}$ & lokal \\
\hline $\begin{array}{l}\text { Usaha pedagang } \\
\text { menetap/ toko }\end{array}$ & $\begin{array}{l}\text { Sekitar jalan } \\
\text { Tunjungan, } \\
\text { Blauran, Praban, } \\
\text { Tanjung Anom. }\end{array}$ & Lokal-regional \\
\hline
\end{tabular}

Sumber: hasil survei

Berdasarkan kondisi iklimnya, wilayah permukiman Tunjungan memiliki kisaran temperatur antara $22,7^{\circ} \mathrm{C}-$ $33,7^{\circ} \mathrm{C}$, meskipun ada kalanya mencapai nilai temperatur maksimum hingga $35,7^{\circ} \mathrm{C}$. Kelembapan maksimumnya mencapai 100\% (di musim penghujan) dan kelembapan minimumnya mencapai titik $25 \%$, dimana tekanan udara berada di kisaran 1.005,8 - 1.016,1 mbs (Bappeko, 2010). 
Berdasarkan topografinya, wilayah kajian memiliki karakter lahan yang relatif datar dan rendah ( 5 meter di atas permukaan air laut) dengan arah aliran permukaan dan saluran drainase sebagian besar menuju ke Utara. Hampir sebagian besar wilayah permukiman UP Tunjungan merupakan kawasan perkerasan terbangun berkepadatan tinggi (daya serap permukaan tanah < limpasan air hujan). Kondisi ini dirasa kurang berimbang dengan tingginya curah hujan di lokasi amatan (rata-rata hariannya mencapai $250 \mathrm{~mm}$ ) dimana seluruh aliran permukaan harus dialirkan oleh saluran drainase.

\section{PEMBAHASAN}

Pendekatan ekologis/ berwawasan lingkungan merupakan pendekatan ilmu yang mengkaji hubungan timbal balik antara makhluk hidup dan lingkungannya (Ardiani, 2015; Yuliani, 2012). Dalam penerapan prinsip ekologis perkotaan, optimalisasi tidak hanya dilakukan pada pemanfaatan Sumber Daya Alam yang tersedia saja, namun juga pada ruang kota sebagai sumber daya alam kota untuk kesejahteraan masyarakat dan lingkungan (Suganda, Ananda, \& Rahmayanti, 2014).

Tuntutan penerapan permukiman sebagai bagian dari rancangan ekologis mengedepankan keberlanjutan jangka panjang kota di berbagai aspek ekonomi, sosial, dan lingkungan. Oleh karenanya, diperlukan analisis strategi penyelesaian masalah ekologis melalui pendekatan konsep lingkungan (arsitektur hijau), ekonomi berwawasan lingkungan, serta sosial (peran serta masyarakat dalam pembangunan). Sebelum mengkaji ketiga aspek tersebut, terlebih dahulu perlu ditelusuri masalah yang ditemui di lapangan beserta usaha-usaha penanganan yang telah dilakukan.

\subsection{Kondisi Eksisting Permukiman}

Tata ruang permukiman di kawasan Segi Empat Emas Tunjungan berkembang secara sporadis dengan jalan lingkungan yang tergolong sempit hampir di seluruh bagian kawasan (Gambar 2). Secara fisik, seluruh sistem jaringan jalannya sudah berupa perkerasan paving dan beton, meskipun ditemukan ada bagian jalan yang mengalami kerusakan (retak dan berlubang). Minimnya alokasi keberadaan ruang terbuka hijau di permukiman menambah daftar permasalahan permukiman. Sejauh ini, terasan kecil/ tepian hunian dimanfaatkan sebagai ruang penyediaan pot-pot tanaman.

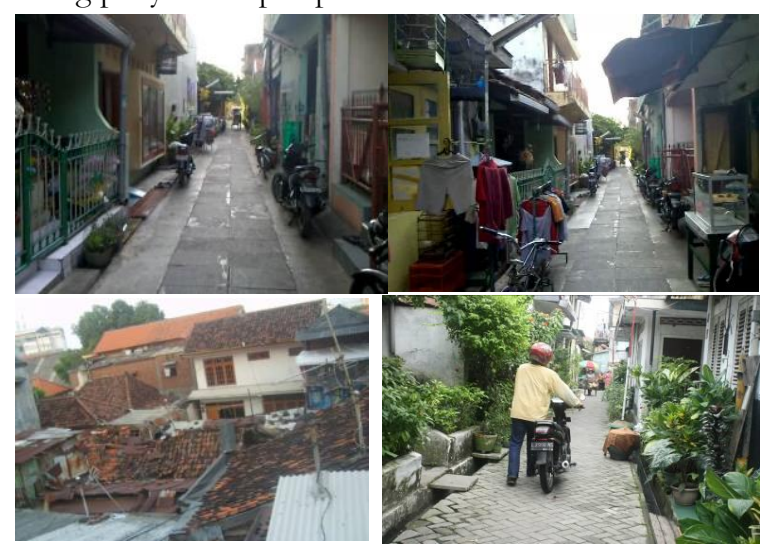

Gambar 2. Kondisi Fisik Permukiman Segi Empat Emas Tunjungan (sumber: hasil survei)

Hampir seluruh badan jalan permukiman Tunjungan memiliki lebar rata-rata 1-2meter (aksesibilitas hanya dicapai kendaraan beroda dua dan pejalan kaki), namun 
ada juga yang memiliki lebar 3-4meter di salah satu bagian koridornya. Meskipun demikian, ruang aksesibilitas koridor jalan tidak bisa efektif karena terhambat penggunaan area parkir kendaraan, tempat jaringan utilitas (kelistrikan), aktivitas menjemur pakaian dan kasur, berdagang, serta penempatan kandang peliharaan dimana tentu saja mempengaruhi estetika perwajahan kampung.

Pengaliran sistem drainase lingkungan ternyata juga tidak diimbangi oleh jalan akses menuju permukiman yang layak. Jalan lingkungan permukiman memiliki kedudukan yang lebih rendah dari jalan utama (arteri primer pada Jalan Praban, Tunjungan, Embong Malang, dan Blauran) (Gambar 3.). Kondisi ini semakin diperlemah dengan keadaan saluran drainase permukiman yang mayoritas terdiri atas sistem tertutup permanen dan semi permanen (buka-tutup) selebar 20$30 \mathrm{~cm}$. Ketika curah hujan tinggi terjadi, timbul genangan banjir tepat di tengah - tengah kawasan permukiman yang mana kerap mengganggu aktivitas di dalam lingkungan permukiman.

Keadaan sanitasi di sebagian permukimannya pun terkesan kumuh dan kotor. Keadaan tersebut dimungkinkan karena faktor tingkat ekonomi penghuni yang berbeda-beda dan keterbatasan lahan dalam penyediaan sanitasi lingkungan yang belum memadai, sehingga berimplikasi pada kemampuan dalam merawat fasilitas yang ada (Nursyahbani \& Pigawati, 2015).

Lebih jauh lagi, kondisi fisik antar bangunannya diperlihatkan saling berdempet tanpa adanya sempadan bangunan. Bangunan jarang memiliki teras halaman dan didirikan tepat di samping bahu jalan. Bangunan memiliki ketinggian lantai berkisar antara 1 - 3 lantai (didominasi 1 lantai) dengan penataan yang tidak beraturan. Dampak penataan bangunan dengan kerapatan tinggi ini disinyalir mampu mempengaruhi permasalahan kesehatan penghuni, seperti dikarenakan faktor kelembaban bangunan, perolehan sinar matahari, dan pengudaraan yang tidak optimal (Breuste, Feldmann, \& Uhlmann, 2013; Udofia, Yawson, Aduful, \& Bwambale, 2014). Ketidaktersediaan jalur evakuasi dan penyelamatan kebakaran juga menjadi kendala keamanan berhuni akibat dampak dari rapatnya hunian terhadap aksesibilitas.

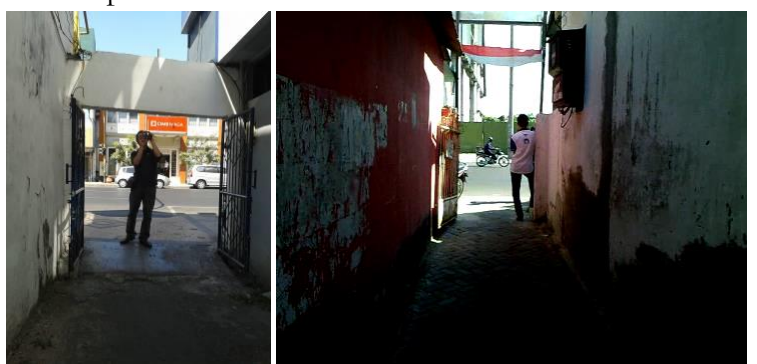

Gambar 3. Jalan Masuk Lingkungan Permukiman yang Menurun (sumber: hasil survei)

Secara non-fisik, keterlibatan partisipatorik masyarakat diperoleh dari kegiatan gotong royong dan kerja bakti warga. Keaktifan masyarakat tergerakkan oleh program kegiatan yang dirancang atas keterlibatan warga, bahkan adapula yang dilakukan secara spontanitas. Masih adanya hubungan bertetangga merupakan bentuk kepedulian antar sesama dikarenakan aktivitas warga yang erat dan saling berdekatan.

Kegiatan perdagangan dan jasa yang bersifat komersialregional lebih banyak didominasi pada jaringan jalan utama di sekitar Segi Empat Emas Tunjungan (area 
Central Bussiness District/ CBD). Sementara di dalam kawasan permukimannya dimanfaatkan untuk kegiatan berdagang (di pagi hari), meskipun aktivitas cenderung sepi karena sebagian besar penghuni bekerja di luar rumah. Pada malam hari, masyarakat juga memanfaatkan ruang untuk aktivitas berdagang dan berinteraksi.

Sejauh ini, usaha dalam meningkatkan kualitas kebersihan, keamanan, peran serta masyarakat terhadap pembangunan lingkungan, serta penghijauan telah dilakukan oleh Pemerintah Kota dan beberapa Perusahaan Swasta melalui perlombaan kebersihan lingkungan. Upaya ini belum mendapatkan hasil yang maksimal sebab minimnya pelopor penggerak masyarakat dalam menjaga kontinuitas.

Beberapa penanganan infrastruktur di wilayah kajian di antaranya juga memperlihatkan pembersihan saluran drainase secara berkala, peninggian lantai rumah sekitar 10-20 cm sehingga kondisi rumah aman 'sementara' dari masuknya air genangan hujan. Sebagai tambahannya, penanganan masalah persampahan juga telah dilakukan secara periodik dan kolektif melalui pengangkutan sampah. Tumpukan sampah menjadi berkurang dan memperbaiki estetika kawasan permukiman terkait persampahan.

\subsection{Strategi Permukiman Ekologis melalui Pendekatan Arsitektur Hijau}

Strategi permukiman berwawasan lingkungan sebagai upaya mengoptimalkan potensi kampung kota dapat dijembatani secara fisik dengan strategi pembangunan kota ekologis, salah satunya melalui pendekatan arsitektur hijau (Sinthia, 2013). Dalam hal ini, arsitektur hijau memiliki peranan dalam mengawal rancangan lingkungan binaan, kawasan, dan bangunan (aspek fisik lingkungan) ke dalam tatanan yang lebih komprehensif dan berlanjut (Karyono, 2010a). Sejumlah elemen rancangan di Kawasan Segi Empat Emas Tunjungan perlu dievaluasi untuk selanjutnya dikaji berdasarkan kriteria-kriteria tertentu dalam strategi yang dicanangkan dalam parameter Ecological Design dan Green Architecture (Karyono, 2010a; Ryn \& Cowan, 2013) berikut.

\section{1) Strategi pemberdayaan warisan lingkungan}

\section{a. Pemberdayaan cultural landscape}

Pemberdayaan lingkungan berarti mengoptimalkan keterlibatan budaya, kultur, dan kebiasaan setempat di dalam pembangunan kawasan. Strategi yang dapat dilakukan di dalam permukiman yaitu pengadaan festival seni dan budaya, serta penggalian dan penjaringan komunitas seni dan kerajinan. Selain untuk menjaga nilai-nilai kelestarian, pemberdayaan mampu memunculkan identitas permukiman yang berkarakter. Sejauh ini, belum terbentuk komunitas seni yang secara giat menghidupkan nilai kultur setempat secara berlanjut.

\section{b. Penghargaan terhadap sejarah}

Permukiman kawasan Segi Empat Emas Tunjungan merupakan bagian dari landmark kolonial bersejarah. Keberadaannya masih dipertahankan hingga sekarang termasuk keberadaan situs makam tokoh masyarakat. Perhatian lebih terhadap penjagaan habitat yang ada dari sektor hunian dan area situs perlu ditekankan melalui peremajaan kawasan agar ekosistem tidak terdegradasi dan bertransformasi penuh ke sektor perdagangan dan jasa. 


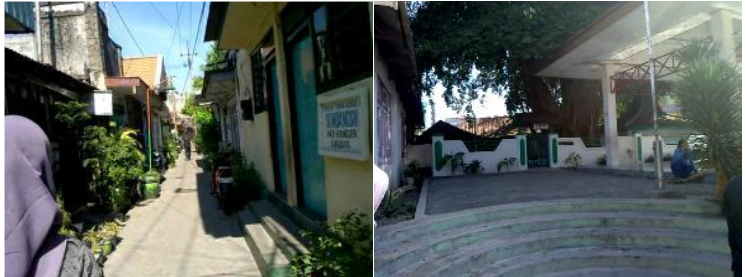

Gambar 4. Penyediaan Sarana Komunitas (kiri); Eksistensi Situs Makam Tokoh Masyarakat (sumber: hasil survei)

2) Strategi penerapan arsitektur hijau sebagai faktor pembangunan fisik

a. Penyeimbangan lingkungan terdegradasi

- Lokasi, pengolahan, dan peningkatan kualitas tapak

Permukiman diapit oleh jalan-jalan utama Surabaya (Jl Praban, Jl Tunjungan, dan Jl Embong Malang). dimana jalan menuju kawasan permukiman diarahkan ke ganggang sempit yang diakses melalui jalan-jalan utama. Kondisi infrastruktur yang demikian diketahui telah memicu permasalahan banjir di beberapa titik kawasan. Srategi yang dapat dilakukan ialah melakukan pemantauan berkala terhadap saluran infrastruktur yang ada, seperti melakukan pembersihan drainase di tiap saluran permukiman. Selain itu, sistem drainase tertutupnya dibuatkan saluran pipa/ tampungan air sebagai upaya pengaliran buangan ke saluran drainase terbuka. Di sisi lain, penerapan material berpori/ conblock/ grassblock juga dipertimbangkan untuk membantu penyerapan genangan dan keberlanjutan perbaikan jalan.

\section{- Jalur pedestrian}

Jalur pedestrian yang ada di permukiman Tunjungan memiliki fungsi ganda dengan penggunaan jalur lalu lalang kendaraan, pedagang keliling, serta kegiatan bersosialisasi dan menjemur pakaian. Ukuran lebar jalan yang sempit memberi kesempatan pejalan kaki menerima manfaat lebih dalam peneduhan koridor di siang hari. Namun, di sisi lain, kondisi ini tetap dirasa mengganggu aktivitas berjalan kaki karena terhambat aktivitas yang lain secara bersamaan. Strategi yang ditawarkan ialah mentertibkan lagi fungsi koridor lebih tepat guna agar tidak mengganggu sirkulasi pejalan kaki.

\section{- Transportasi kawasan}

Penggunaan sarana transportasi masal dapat mengoptimalkan perpindahan manusia serta mereduksi kebutuhan energi dan pencemaran polusi udara. Kondisi ini telah didukung oleh keberadaan transportasi umum di luar permukiman dimana di dalam lingkungan permukimannya diakomodasi dengan berjalan kaki dan kendaraan beroda dua (meskipun keadaan ini terkondisikan karena sempitnya lahan dan rendahnya status kepemilikan kendaraan).

b. Pendayagunaan energi, kesehatan, dan keamanan

\section{- Pereduksian panas matahari}

Perolehan panas matahari yang masuk ke dalam hunian dapat direduksi dengan pemanfaatan vegetasi (tanaman rambat), pemberian teduhan di sisi dinding bangunan yang terpapar panas, serta pengaturan ulang organisasi ruang. Ketidaktepatan pengaturan ruang (maupun penempatan orientasi bangunan) dapat berdampak pada peningkatan suhu di ruang yang sisinya mendapatkan 
panas berlebih. Hal inilah yang terjadi pada kondisi eksisting akibat dari keterbatasan lahan dan kerapatan bangunan.

\section{- Pelepasan panas bangunan}

Hunian di permukiman kampung Tunjungan belum memiliki manajemen pelepasan panas bangunan yang optimal dikarenakan unit-unit huniannya tumbuh secara acak, tidak teratur, dan serba terbatas. Strategi yang dapat dilakukan ialah pendekatan ke masing-masing unit bangunan untuk memaksimalkan sirkulasi udara silang (jika memungkinkan) dan memberikan ruang sirkulasi udara pada atap baik secara alami ataupun mekanis melalui turbin ventilator.

- Penghindaran radiasi matahari mengenai bidang kaca

Banyak sisi transparan pada hunian tidak memperhatikan arah perletakkannya terhadap keterimaan panas. Kondisi hunian yang terbangun secara rapat dan tak beraturan di lahan yang sempit menyebabkan terbatasnya sisi dinding untuk berhubungan langsung dengan ruang luar. Sejauh ini, solusi yang telah dilakukan ialah memasang tirai pada sisi bidang transparan tersebut. Bagaimanapun, bila ruang di sisi dalam bidang transparan tidak mempunyai pengaliran sirkulasi udara yang baik, maka panas yang masuk tetap terperangkap di dalam ruangan. Oleh karenanya, strategi yang ditawarkan ialah memberi naungan (selasar/ kanopi/ transisi ruang/vegetasi) pada area bidang transparan di sisi keterimaan panas matahari berlebih (sisi Barat-Barat Laut-Barat Daya, (Latifah, 2015)) agar tidak terkena panas matahari langsung dan atau memberi/ menambah bukaan jendela/ dinding berongga pada sisi dinding lainnya untuk memaksimalkan sirkulasi udara.

\section{- Pemanfaatan cahaya matahari sebagai} penerangan ruang

Cahaya matahari yang masuk ke dalam bangunan melalui bidang transparan juga dapat berfungsi sebagai penerangan alami. Kerapatan dan keterhalangan bangunan menyebabkan penghuni permukiman tidak dapat mengoptimalkan sumber cahaya alami. Hal ini memperlihatkan bahwa terjadi dominasi penggunaan cahaya buatan dalam bangunan permukiman di siang hari. Strategi yang dapat diupayakan yaitu melakukan penataan ulang pada unit-unit hunian secara menyeluruh; pembuatan lubang cahaya (pada atap maupun sisi dinding yang tidak terkena radiasi secara langsung) dan dihubungkan dengan ruang-ruang yang membutuhkan pencahayaan; serta penerapan teknologi light pipes/ light shelves sebagai upaya pengaliran cahaya tidak langsung.

\section{- Pengaplikasian warna dan tekstur dinding luar bangunan}

Penggunaan warna dinding di luar bangunan permukiman cenderung mengaplikasikan warna terang. Cukup menguntungkan ketika efek psikologis yang terjadi di lingkungan menjadi positif dikarenakan kesan ruang yang lebih luas, aman, dan terang terhadap jalurjalur jalan yang sempit.

\section{- Perancangan ruang dalam}

Dalam arsitektur hijau, kenyamanan fisik manusia yang terkait aspek spasial, termal, visual, auditorial, serta olfactual harus mampu dipenuhi ruang dalam bangunan (Karyono, 2010b). Upaya ini dimaksudkan sebagai 
cerminan derajat keberhasilan bangunan dalam memfasilitasi pengguna beraktivitas, sebagai contoh pada penilaian kualitas udara ruang.

Arsitektur hijau menggarisbawahi pentingnya udara dengan kualitas yang baik dalam menunjang kehidupan manusia. Sejumlah aktivitas manusia secara langsung atau tidak langsung dapat mencemari udara. Kegiatan yang terkait dengen merokok, pembakaran bahan bakar minyak, atau bahan lain melepaskan sejumlah gas CO2 dan polutan lain dapat menurunkan kualitas udara. Kendaraan bermotor pun secara langsung dapat mencemari udara dalam kadar yang variatif tergantung dari jenis kendaraannya. Selain itu, penurunan kualitas udara juga dapat disebabkan oleh ruang yang tertutup tanpa banyak mendapatkan pertukaran udara dari luar. Strategi yang dapat diupayakan yaitu seperti halnya mengoptimalkan pertukaran udara melalui penerapan bukaan yang tepat.

- Perancangan ruang luar (selaras dalam meminimalkan efek "heat urban island")

Pembangunan kawasan secara fisik perlu diimbangi dengan pembangunan lingkungan sekitar agar tidak terjadi penurunan kualitas lingkungan. Hampir seluruh rancangan ruang luarnya menggunakan elemen hardscape/ material keras seperti plesteran semen, cor, dan paving yang rata yang sebenarnya bertujuan demi kenyamanan berjalan kaki. Penghijauannya pun sebatas perletakkan pot-pot di depan rumah. Bagaimanapun, rancangan tersebut perlu diimbangi dengan rancangan softscape yang memadai (penyediaan lahan/ area sebagai fungsi pertamanan, penerapan koridor hijau, pemanfaatan bilik/ area vertikal/ atap sebagai 'kebun mandiri' agar radiasi yang diterima tidak sepenuhnya dipantulkan ke kawasan, melainkan terserap lebih banyak ke elemen softscape. Sebagai tambahannya, elemen softscape juga bermanfaat dalam penyerapan polusi udara lingkungan.

\section{c. Pembangunan kembali bio-region}

\section{- Material terbarukan}

Material terbarukan memiliki inovasi yang tidak sekedar 'baru', melainkan berupaya menjaga keberlangsungan lingkungan melalui penerapan bahan-bahan yang ramah lingkungan. Kondisi yang terjadi ialah penggunaan material terbarukan (renewable materials) belum terimplementasikan karena minimnya pengetahuan dan kesadaran warga dalam menanggapi potensi dan keberadaan material. Sosialisasi dan dukungan kepada warga diperlukan dalam hal memanfaatkan bahanbahan alam sekitar sebagai material terbarukan secara tepat guna.

\section{- Material bekas}

Hunian pada permukiman Segi Empat Emas Tunjungan belum melakukan pemanfaatan material bekas secara menyeluruh. Padahal penggunaan ulang dari bahan dapat dijadikan pilihan warga karena faktor keekonomisan. Strategi pengelolaan diperlukan agar pemanfaatannya dapat dikendalikan dan memiliki keberlanjutan, yaitu berupa sosialisasi percontohan tentang pemisahan bahan-bahan bekas (sebagai langkah awal). Pada limbah bangunan khususnya, beberapa material yang masih layak dapat digunakan kembali atau diolah sebagai bahan non-struktural bangunan. 


\section{- Material sehat (tidak mengkontaminasi lingkungan)}

Bangunan di permukiman Tunjungan dibangun seadanya tanpa memperhatikan batas kemampuan postoccupancy bahan. Bahan cenderung digunakan dalam kurun waktu lama sampai mengalami kerusakan akibat purna huni dimana tentu saja dapat memberi dampak tak langsung pada kesehatan. Beberapa pengaplikasian materialnya pun masih ada yang tambal sulam dikarenakan faktor perekonomian masyarakat. Strategi yang dapat dilakukan ialah melakukan sosialisasi dan kontrol lapangan terhadap penggunaan bahan-bahan, serta memberikan solusi pemilihan dan penerapan bahan material.

\section{d. Perbaikan biosfer}

Perbaikan biosfer dapat diupayakan dengan melakukan restorasi maupun konservasi sumber daya pada udara, air, lahan, energi, biomass, makanan, keanekaragaman, habitat, ecolinks, maupun limbah. Pada air hujan dan air limbah di permukiman (misalnya), kondisinya terbuang secara sia-sia tanpa dikelola dan dimanfaatkan secara maksimal.

Strategi yang dapat dilakukan ialah melakukan pengelolaan air hujan dengan mengunakan sistem penampungan air warga sehingga dapat digunakan untuk mengairi tanaman dan berbagai keperluan rumah tangga. Di sisi lain, limbah buangan cair rumah tangga dapat dikontrol dan difilterisasi melalui sistem pengolahan limbah komunal yang disiapkan di lingkungan permukiman sehingga dapat meminimalisir pencemaran lingkungan.

\subsection{Strategi Pembangunan Ekonomi Berwawasan Lingkungan}

Pembangunan berwawasan lingkungan tidak terlepas dari pembangunan ekonomi. Pembangunan ekonomi yang sporadis tanpa memperhatikan kondisi lingkungan yang ada dapat berdampak pada penurunan kualitas lingkungan yang drastis. Pembangunan ekonomi harus memperhatikan dampaknya terhadap lingkungan dan saling berkolaborasi dalam pembangunan kawasan. Kesemuanya ini tentu saja dapat memberi dampak positif pada peningkatan ekonomi masyarakat. Pembangunan ekonomi kawasan studi dibagi menjadi dua bagian didasarkan.

1) Pengelolaan lingkungan yang berdampak langsung pada kelestarian lingkungan dan peningkatan ekonomi masyarakat jangka pendek dan menengah

\section{a. Memelihara lingkungan alam}

Pemeliharaan lingkungan dapat dilakukan dengan pengolahan area/ koridor/ sisi bangunan sebagai Ruang Terbuka Hijau. Selain berupaya membantu program penghijauan kawasan padat, strategi ini dapat memberi nilai ekonomi lingkungan sebagai daya tarik kawasan.

\section{b. Mendukung pertanian lokal}

Wilayah kampung dapat menggalakkan penghijauan yang berorientasi kepada tanaman pangan. Sistem yang dapat diterapkan ialah sistem aeroponik dan hidroponik sederhana yang ditempatkan pada sebagian hunian yang memiliki lahan cukup lapang/ vertical farming/ bagian atap rumah (dengan penyesuaian struktur).

c. Memaksimalkan konservasi di segala bidang Perencanan konservasi kawasan dapat dilakukan pada air dan tanah, jenis vegetasi, kuliner, historis. Perlu 
ditelusuri karakteristik dan potensi lingkungan yang mampu dioptimalkan untuk keberlanjutan lingkungan dan nilai ekonomi kawasan.

\section{d. Pemerataan sistem fasilitas kawasan}

Sistem fasilitas kawasan merupakan hal yang penting dalam mendukung pergerakan manusia. Penekanan dapat difokuskan pada perbaikan kualitas infrastruktur yang memberi kemudahan, membuat nyaman, dan aman baik bagi para penghuni maupun pengunjung kawasan. Infrastruktur tersebut misalnya: penerangan jalan umum, telepon umum darurat, fire bydran lingkungan, rambu ramah lansia dan difabel, serta mural pesan.

\section{e. Menggunakan energi terbaharukan}

Penggunaan energi terbaharukan dimungkinkan dengan pemanfaatan sistem pemurnian air berbasis vegetasi yang sekaligus berperan sebagai penyelaras estetika jalur pedestrian; serta sistem produksi listrik tenaga kinetik pada jalur pedestrian ataupun penyerapan sel surya pada area-area yang dikenai panas matahari. Keseluruhan upaya ini tetap memerlukan dukungan dari pihak yang berkompenten.

\section{f. Mengetrapkan program 3R}

Dalam mengurangi dampak lingkungan terhadap pencemaran, penerapan metode Reduce, Reuse, Recycle diperlukan dalan kawasan. Strategi 3R dilakukan melalui penerapan material bangunan dan pengolahan limbah domestik permukiman. Dengan adanya sosialisasi dan pelatihan yang memadai diharapkan konsep $3 \mathrm{R}$ dapat menghasilkan produk yang berdaya guna kembali dan bernilai ekonomi.
2) Peningkatan ekonomi masyarakat secara tidak langsung dan dalam waktu jangka menengah dan jangka panjang

a. Perhitungan cermat untuk pembangunan ekonomi

Perhitungan dapat dilakukan dengan menganalisis peluang industri pasar di area pusat kota Surabaya untuk selanjutnya dikembangkan menjadi potensi keunggulan industri permukiman Segi Empat Emas Tunjungan. Ketika sudah dikembangkan, penyediaan lapangan pekerjaan yang padat karya akan terbuka lebar sehingga secara khusus dapat mengurangi tingkat pengangguran di permukiman.

\section{b. Membangun dengan mix-use berorientasi pada pedestrian dan komunitas}

Wilayah kampung terletak dalam posisi strategis yang menghubungkan tiga jalan utama (Tunjungan, Praban, Embong Malang). Jalur setapak di dalam kampung dirancang sedemikian rupa sehingga 'memaksa' penghuni maupun pengunjung mengakses dengan berjalan kaki. Namun tetap memperhatikan keberlangsungan pelaku usaha di sentra-sentra yang sudah dialokasikan dalam lingkup permukiman.

Sosialisasi dalam mengelola lingkungan dan kesadaran terhadap lingkungan sangat penting dalam keberlanjutan perekonomian sebuah kawasan. Dengan meningkatnya perekonomian kawasan, artinya permukiman secara mandiri sudah mampu melangsungkan kontinuitas kehidupannya. 


\subsection{Strategi Peran Masyarakat Setempat dalam Pembangunan Berwawasan Lingkungan}

Keterlibatan masyarakat dalam pembangunan berarti ada peran serta masyarakat secara partisipatif dalam proses penyusunan rencana pembangunan, proses pembangunan, dan pengendalian/kontrol pasca pembangunan. Pembangunan berkelanjutan dapat tercapai jika semua stakeholder berperan aktif dalam pembangunan di lingkungan tersebut. Beberapa tahapan pembangunan partisipatif yang dilakukan untuk mencapai pembangunan yang ideal di antaranya: Proses penyusunan partisipasi masyarakat dalam perencanaan; Peran kelembagaan masyarakat dalam pembangunan partisipatif; serta Implementasi pembangunan partisipatif (Gambar 5.)

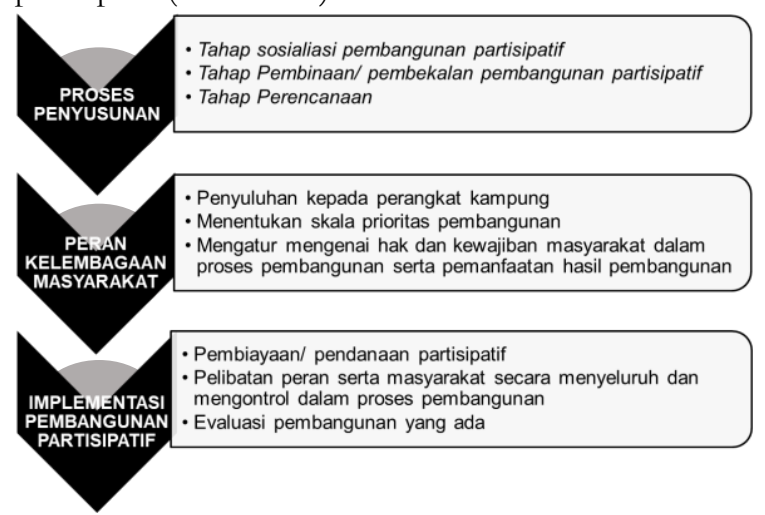

Gambar 5. Tahap Partisipasi Masyarakat (sumber: hasil analisis)

Stakeholder pada sektor pembangunan ini terdiri dari tokoh masyarakat, ketua RT/RW, kader lingkungan, dan LSM serta masyarakat itu sendiri dimana masingmasing fungsi dijabarkan sebagai berikut.
1. Tokoh masyarakat, ketua RW/RT, dan pemerintah (dinas terkait), yaitu sebagai fasilitator terhadap perencanaan program.

2. Kader lingkungan dan LSM, yaitu sebagai pendamping selama berjalannya proses pembangunan.

3. Swasta, yaitu sebagai pendukung (finansial khususnya) dalam kegiatan perencanaan.

Dalam pemahaman partisipatif, penanaman kesadaran dan kepekaan masyarakat dalam pembangunan berwawasan lingkungan juga penting dan dapat digencarkan sejak usia dini melalui pendekatanpendekatan komunitas.

\section{KESIMPULAN}

\subsection{Kesimpulan}

Penelitian yang telah dilakukan pada area studi pemukiman padat penduduk di Segi Empat Emas Tunjungan menghasilkan temuan berbagai macam potensi sekaligus problematika lingkungan. Permasalahan yang paling mendasar dari pemukiman tersebut adalah tidak adanya regulasi yang mengatur tumbuh kembangnya pemukiman secara ketat sehingga pertumbuhan permukiman tumbuh tak terkendali. Perlu adanya pengaturan sistem yang jelas tidak hanya pada aspek lingkungan fisik, namun juga pengaturan kendali dan dukungan penuh di bidang ekonomi dan masyarakat. Sistem, kendali, dan dukungan harus terencana, bertanggung jawab, dan sesuai dengan daya dukung lingkungannya demi perbaikan kualitas lingkungan menjadi berwawasam lingkungan. 


\subsection{Saran}

Pengambilan tema pembangunan berwawasan lingkungan ini berusaha mencari solusi yang membawa keuntungan bagi lingkungan di area penelitian sekaligus membawa dampak positif bagi lingkungan sekitarnya. Oleh karenanya, solusi yang ditawarkan masih berupa gambaran konsep secara keseluruhan yang memungkinkan dikaji lebih lanjut berdasarkan penilaian urgensi dalam penerapan di lapangan.

\section{REFERENSI}

Ardiani, Y. M. (2015). Sustainable Arcbitecture, Arsitektur Berkelanjutan. Jakarta: Erlangga.

Bappeko. (2010). Rencana Detail Tata Ruang Kota Surabaya, Unit Pengembangan Tunjungan.

Breuste, J., Feldmann, H., \& Uhlmann, O. (2013). Urban Ecology. Leipzig: Springer Science \& Business Media.

Damayanti, R. (2017). "Kampung Kota” as Third Space in an Urban Setting: The Case Study of Surabaya, Indonesia. In Q. M. Zaman \& I. Troiani (Eds.), The Urban Book Series (pp. 127-139). Springer International Publishing, Cham (First online 09 July 2017).

Daniels, T. (2017). Environmental Planning Handbook. Oxon: Routledge.

Djau, B. (2010). Konservasi Kawasan Segi Empat Emas Tunjungan Surabaya. In Seminar Nasional tentang Arsitektur [di] Kota "Hidup dan Berkebidupan di Surabaya" (pp. 60-68). Surabaya: Jurusan Arsitektur Universitas Kristen Petra.

Hall, P., \& Pfeiffer, U. (2013). Urban Future 21: A Global Agenda for Twenty-First Century Cities. London: Routledge.

Hamidah, N., Rijanta, R., Setiawan, B., \& Marfai, M. A.
(2016). Kampung Sebagai Model Permukiman Berkelanjutan. INERSLA, XII(2), 114-124.

Jazuli, A. (2015). Dinamika Hukum Lingkungan Hidup dan Sumber Daya Alam Dalam Rangka Pembangunan Berkelanjutan. Jurnal Rechtsvinding, 4(2), 181-197.

Karyono, T. H. (2010a). Green Architecture: Pengantar Pemahaman Arsitektur Hijau di Indonesia. Jakarta: Raja Grafindo Persada.

Karyono, T. H. (2010b). Kenyamanan Termal dan Penghematan Energi: Teori dan Realisasi dalam Desain Arsitektur. In Seminar dan Pelatiban Ikatan Arsitek Indonesia (LAI), Gedung Jakarta Desain Center, 20 Maret 2010. Jakarta.

Latifah, N. L. (2015). Fisika Bangunan 1 (I). Jakarta: Griya Kreasi (Penebar Swadaya Group).

Nazaruddin, T. (2015). Perencanaan Kota secara Komprehensif Berbasis Hukum Integratif menuju Pembangunan Kota Berkelanjutan. Jurnal Cita Hukum, II(2).

Nursyahbani, R., \& Pigawati, B. (2015). Kajian Karakteristik Kawasan Pemukiman Kumuh di Kampung Kota (Studi Kasus: Kampung Gandekan Semarang). Teknik PWK, 4(2), 267281.

Ryn, S. Van der, \& Cowan, S. (2013). Ecological Design, Tenth Anniversary Edition (revised). Washington, DC: Island Press.

Sinthia, S. A. (2013). Sustainable Urban Development of Slum Prone Area of Dhaka City. In Poceedings of World Academy of Science, Engineering and Technology (Vol. 7, pp. 701-708). World Academy of Science, Engineering and Technology (WASET).

Suganda, E., Ananda, S., \& Rahmayanti, H. (2014). Konsep Kota Ekologis sebagai Kota Ekonomis yang Berkelanjutan (Kajian Infrastruktur Kota). Jakarta: Program Studi Ilmu Lingkungan, Universitas 
Indonesia-Program Pascasarjana.

Udofia, E. A., Yawson, A. E., Aduful, K. A., \& Bwambale, F. M. (2014). Residential characteristics as correlates of occupants' health in the greater Accra region, Ghana. BMC Public Health, 14(1), 1-13.

Widjaja, P. (2013). Kampung-Kota Bandung. Yogjakarta: Graha Ilmu.

Yuliani, S. (2012). Paradigm of Ecological Architecture of Kenneth Yeang As a Design Method of Environmental Friendly. In 2nd CONVEEESH \& 13Th SENVAR International Conference. Yogyakarta: Architecture Department DWCU Yogyakarta. 